\title{
Effect of Multispecies Microbial Consortia on Microbially Influenced Corrosion of Carbon Steel
}

\author{
Hoang C. Phan ${ }^{1, *(\mathbb{O})}$, Linda L. Blackall ${ }^{2}(\mathbb{D})$ and Scott A. Wade ${ }^{1, *}$ \\ 1 Faculty of Science, Engineering and Technology, Swinburne University of Technology, \\ Hawthorn, VIC 3122, Australia \\ 2 School of BioSciences, University of Melbourne, Melbourne, VIC 3052, Australia; \\ linda.blackall@unimelb.edu.au \\ * Correspondence: hoang.phan@virbac.vn (H.C.P.); swade@swin.edu.au (S.A.W.); \\ Tel.: + 84-9-3396-8650 (H.C.P.); Tel.: +61-3-9214-4339 (S.A.W.)
}

Citation: Phan, H.C.; Blackall, L.L.; Wade, S.A. Effect of Multispecies Microbial Consortia on Microbially Influenced Corrosion of Carbon Steel. Corros. Mater. Degrad. 2021, 2 133-149. https://doi.org/10.3390/ cmd2020008

Academic Editor: Philippe Refait

Received: 1 February 2021

Accepted: 18 March 2021

Published: 25 March 2021

Publisher's Note: MDPI stays neutral with regard to jurisdictional claims in published maps and institutional affiliations.

\begin{abstract}
Microbially influenced corrosion (MIC) is responsible for significant damage to major marine infrastructure worldwide. While the microbes responsible for MIC typically exist in the environment in a synergistic combination of different species, the vast majority of laboratory-based MIC experiments are performed with single microbial pure cultures. In this work, marine grade steel was exposed to a single sulfate reducing bacterium (SRB, Desulfovibrio desulfuricans) and various combinations of bacteria (both pure cultures and mixed communities), and the steel corrosion studied. Differences in the microbial biofilm composition and succession, steel weight loss and pitting attack were observed for the various test configurations studied. The sulfate reduction phenotype was successfully shown in half-strength marine broth for both single and mixed communities. The highest corrosion according to steel weight loss and pitting, was recorded in the tests with $D$. desulfuricans alone when incubated in a nominally aerobic environment. The multispecies microbial consortia yielded lower general corrosion rates compared to D. desulfuricans or for the uninoculated control.
\end{abstract}

Keywords: corrosion; metabarcoding; MIC; multispecies; SRB

\section{Introduction}

The corrosion of metals immersed in the marine environment is a well-known issue, which can also be accelerated by the activities of a diverse range of microbes in a process known as microbially influenced corrosion (MIC) [1,2]. An example of MIC is the rapid failure of metal structures, typically in the form of localised corrosion around low tide level, which is referred to as accelerated low water corrosion (ALWC) [3,4]. ALWC has been reported on steel structures (e.g., sheet piling) in many ports and harbors worldwide. The reduction in thickness of steel pilings, which can be up to several $\mathrm{mm} / \mathrm{yr}$, is one of indications used to diagnose ALWC [5]. In the UK alone, the short-term cost of ALWC was estimated to be $\sim £ 250$ million [3]. Methods to minimise ALWC include the application of cathodic protection, coatings and the use of special grade steel. Further work, however, is required in order to obtain a better understanding of the complex roles and types of microbes involved in ALWC.

Biofilm formation is a biological process that takes place in humid/aquatic environments, and involves a series of developmental steps. In the natural environment these intricate microbial structures typically contain a diverse range of microbes with complex interactions [6,7]. In relation to ALWC, different microbes are likely to play specific roles in the overall corrosion process, including the development of a biofilm on the steel structure, nutrient provision/cycling, as well as producing and maintaining an anaerobic environment. Specific microbes are responsible for the corrosion process $[5,8,9]$. Sulfate reducing bacteria (SRB), e.g., Desulfovibrio desulfuricans, are probably the best known bacterial group in relation to microbial corrosion and ALWC $[10,11]$. The SRB corrosion process is typically 
associated with a black biofilm on the surface and localised corrosion underneath [12]. In addition to SRB, sulfur oxidising bacteria (SOB) have been implicated in ALWC, and the presence of both microbial groups will contribute to the sulfur cycle and subsequent corrosion $[5,8,13-17]$.

While there have been a large number of studies of MIC in the laboratory, most of these have failed to replicate the accelerated corrosion rates observed in the field. One of the possible reasons for this is that most tests use single microbial strains in the experiments (most commonly SRB), which is very different to the mixed microbial species found in biofilms associated with accelerated corrosion in the real environment $[9,18-21]$. Another possible reason is that the testing arrangement used (e.g., test media, oxygen levels and test duration) may influence the processes (abiotic and biotic) required for the accelerated corrosion.

Various laboratory MIC experiments have employed undefined combinations of microbes (e.g., [5,22-25]). While this might be more similar to the field situation, the largely unknown combinations of microbes make replication impossible and the roles of any individual species cannot be determined. Several MIC studies using known microbial strains in various combinations have been undertaken, and have showed how the strains collectively affect corrosion (see Table S1). In some of the latter, the multispecies combinations have led to increased corrosion and in others decreased corrosion.

The mechanisms responsible for MIC are hypothesised to include transfer of electrons from the metal of interest to the SRB and/or biochemicals produced as part of metabolic processes $[26,27]$. Both require the presence of a suitable electron donor and electron acceptor. The artificial supply of electron donors could facilitate increased corrosion compared to real world scenarios since seawater typically has relatively low levels of organic carbon sources [28]. Several researchers have shown that different test media used in MIC studies can affect the level of corrosion [29-31]. Additionally, specific strains of SRB (e.g., Desulfopila corrodens and Desulfovibrio sp. strain IS7) have been linked to the direct electron uptake from an iron/steel surface [26] and have also been detected in field studies of ALWC $[9,17,23]$.

This research adds to the understanding of the effect of multispecies microbial consortia in relation to microbial corrosion such as ALWC. The work involved exposing marine grade steel to an ALWC biofilm from a marine environment, pure culture isolates from an ALWC biofilm or adjacent locations, D. desulfuricans or to an uninoculated media (i.e., negative control). The hypothesis of this work was that the combinations of microbes would produce increased rates of corrosion compared to tests with single isolates or an uninoculated control.

\section{Materials and Methods}

\subsection{Steel Test Coupons}

Marine grade DH36 carbon steel [32] was chosen for this research due to its widespread use in shipbuilding and offshore structures. The metal coupon dimensions were $25 \mathrm{~mm} \times 25 \mathrm{~mm}$ with a thickness of $6 \mathrm{~mm}$. A $2 \mathrm{~mm}$ diameter hole was drilled in each coupon near the middle of one of the edges (3-4 $\mathrm{mm}$ from the edge) to allow coupons to be hung vertically in the aqueous corrosion tests. The top and bottom surfaces of the coupons were prepared using an automatic grinding machine (Tegramin-25, Struers, Cleveland, OH, USA) with a series of silicon carbide papers i.e., 320, 500 and 1200 grit. The edges were manually ground with 320 grit silicon carbide paper. After grinding, the coupons were cleaned by immersing in acetone in an ultrasonic bath for $8 \mathrm{~min}$, rinsed thoroughly with distilled water and then absolute ethanol, and finally dried under warm air. Coupon weight was measured using a high accuracy analytical balance (MS205DU, readability $0.01 \mathrm{mg}$, Mettler Toledo, Mississauga, Canada) shortly before the corrosion tests. 


\subsection{Bacteria and Test Media Details}

The four marine isolates were Halomonas korlensis, Bacillus aquimaris, Prolixibacter bellariivorans and Sulfitobacter pontiacus. Their presumed phenotypes cover a range of potential functions relevant to oxygen tolerance, biofilm formation and MIC. H. korlensis is a denitrifier/nitrate-nitrite reducing facultative aerobe [33] that was isolated from marine sediment [21]. B. aquimaris is a nitrate/metal ion utilising aerobe found in marine environments/biofilms/corrosion steel surfaces [34,35] that was isolated from an orange ALWC tubercle [36]. P. bellariivorans is an iron-relating/sugar-fermenting anaerobe $[37,38]$ that was isolated from an orange ALWC tubercle [36]. Finally, S. pontiacus is an obligate aerobe which belongs to the Rhodobacteraceae group which are noted for surface association [6] and can reduce thiosulfate and sulfite to sulfate [39]. It was isolated from a microbial test kit (used to determine ALWC microbial functions) that was inoculated with an ALWC tubercle sample.

SRB are frequently associated with microbial corrosion (including ALWC), and a culture collection strain of an SRB, D. desulfuricans (ATCC 27774), was used. In addition to the five pure cultures, a consortium of microbes found in an orange tubercle from a suspected case of ALWC on steel sheet piling was also used in one of the test conditions [36].

Pure cultures of the marine isolates (stored at $-80^{\circ} \mathrm{C}$ in glycerol), were freshly grown on marine agar (MA, BD Difco, Franklin Lakes, NJ, USA) plates in an aerobic environment. These cultures were then used to inoculate $45 \mathrm{~mL}$ volumes of autoclaved $\left(121^{\circ} \mathrm{C}, 1 \mathrm{~atm}\right.$ for $16 \mathrm{~min}$ ) half-strength marine broth ( $\mathrm{MB} \frac{1}{2}$, BD Difco, Franklin Lakes, NJ, USA), which were incubated aerobically at $25^{\circ} \mathrm{C}$ for $72 \mathrm{~h}$. Since MB has relatively high nutrient levels, it was diluted to better mimic seawater. Plate counts on MA were performed for all culture broths using serial ten-fold dilution and triplicate plating.

D. desulfuricans was grown in tryptic soy broth (Merck, Darmstadt, Germany), supplemented with sodium lactate $(4 \mathrm{~mL} / \mathrm{L})$ and magnesium sulfate $(2 \mathrm{~g} / \mathrm{L})$. The medium was adjusted to $\mathrm{pH} 7.5$ prior to autoclaving $\left(121^{\circ} \mathrm{C}, 1 \mathrm{~atm}\right.$ for $\left.16 \mathrm{~min}\right)$, after which $0.5 \mathrm{~g} / \mathrm{L}$ of $0.22 \mu \mathrm{m}$ filter-sterilised ferrous ammonium sulfate was added. D. desulfuricans was incubated in an anaerobic jar at $25^{\circ} \mathrm{C}$ for $72 \mathrm{~h}$, with a gas generator sachet (AnaeroGen, Oxoid, Basingstoke, Hampshire, UK) and indicator (Resazurin, Oxoid, Basingstoke, Hampshire, UK). A black culture broth was obtained after incubation, which is an indication of ferrous sulfide production due to sulfate reduction. Plate counts of bacteria were performed anaerobically on modified tryptic soy agar (TSA+, prepared as for the modified tryptic soy broth but with $1.5 \%$ agar included prior to autoclaving).

An orange tubercle from an ALWC setting had been sampled previously and was stored frozen at $-80{ }^{\circ} \mathrm{C}$. The ALWC consortia inoculum for this work was prepared by adding $2.5 \mathrm{~mL}$ of thawed inner and $2.5 \mathrm{~mL}$ of outer tubercle layers to $45 \mathrm{~mL}$ of sterile MB1/2 broth $\left(10 \%\right.$ inoculation), and incubated aerobically at $25^{\circ} \mathrm{C}$ for $72 \mathrm{~h}$. All liquid cultures were gently shaken $(\sim 10 \mathrm{~s})$ once a day to help stimulate microbial growth.

Corrosion tests were performed in $500 \mathrm{~mL}$ sterilised glass bottles containing $350 \mathrm{~mL}$ of sterile $\mathrm{MB} \frac{1}{2}$ with each containing a sterile test coupon suspended by Nylon string. The coupons and Nylon string were sterilised by immersion in absolute ethanol (Merck) for $30 \mathrm{~min}$, then drying in a sterile dry bottle. Subsequently coupons were placed close to a Bunsen flame $(10-15 \mathrm{~cm})$ for 1-2 min to remove any excess ethanol prior to starting the corrosion tests. For the tests with pure cultures or orange tubercle material, $2 \mathrm{~mL}$ volumes of their $72 \mathrm{~h}$ culture broths were added and mixed thoroughly. A total of six test configurations were carried out (Table 1). All of the tests were nominally aerobic except for the test with $D$. desulfuricans (T6) for which anaerobic conditions were obtained by placing the test bottles in individual anaerobic bags together with AnaeroGen sachets and resazurin indicators (Oxoid). All the treatments were conducted statically with 6 individual replicates. All bottles were incubated in a Thermoline Scientific, Australia incubator at $25^{\circ} \mathrm{C}$. 
Table 1. Relative abundance of microbes inoculated in laboratory corrosion tests and incubated at $25^{\circ} \mathrm{C}$ in aerobic or anaerobic conditions.

\begin{tabular}{|c|c|c|}
\hline Test (Incubation Atmosphere) & Brief Description & Microbes (cfu/mL) \\
\hline T1 (aerobic) & No inoculum & None \\
\hline T2 (aerobic) & Orange tubercle & $\begin{array}{l}\text { Diverse consortium from an orange tubercle on steel } \\
\text { sheet piling }\left(\geq 10^{5}\right)\end{array}$ \\
\hline T3 (aerobic) & D. desulfuricans & D. desulfuricans $\left(2 \times 10^{6}\right)$ \\
\hline T4 (aerobic) & Four marine isolates & $\begin{array}{l}\text { B. aquimaris }\left(9 \times 10^{5}\right) \text {, H. korlensis }\left(3 \times 10^{5}\right) \text {, } \\
\text { S. pontiacus }\left(3 \times 10^{6}\right) \text {, P. bellariivorans }\left(7 \times 10^{4}\right)\end{array}$ \\
\hline T5 (aerobic) & $\begin{array}{l}\text { Four marine isolates }+ \\
\text { D. desulfuricans }\end{array}$ & $\begin{array}{c}\text { D. desulfuricans }\left(2 \times 10^{6}\right) \text {, B. aquimaris }\left(9 \times 10^{5}\right) \text {, } \\
\text { H. korlensis }\left(3 \times 10^{5}\right) \text {, S. pontiacus }\left(3 \times 10^{6}\right) \text {, } \\
\text { P. bellariivorans }\left(7 \times 10^{4}\right)\end{array}$ \\
\hline T6 (anaerobic) & D. desulfuricans & D. desulfuricans $\left(2 \times 10^{6}\right)$ \\
\hline
\end{tabular}

\subsection{Corrosion Tests}

The duration of the corrosion tests was 8 weeks. Testing six replicates allowed a range of different studies to be performed using separate coupons. Periodic photos of test bottles were taken to record any changes in media or test coupons.

A total of $40 \mathrm{~mL}$ of fresh sterile $\mathrm{MB} \frac{1}{2}$ was added into each test bottle fortnightly (i.e., fed-batch culture) to help maintain microbial viability during the study period. Sampling of the corrosion tests for bacterial counts was undertaken at weeks 2, 4 and 8 of incubation. This involved pipetting $10 \mathrm{~mL}$ of the culture $(5 \mathrm{~mL}$ from near the test medium surface and $5 \mathrm{~mL}$ near the bottom of the medium) before nutrient amendment. Bacterial counts were obtained using MA plates for aerobic (T1-T5, Table 1$)$ and TSA ${ }^{+}$plates for anaerobic (T6, Table 1) corrosion test using serial ten-fold dilutions and duplicate plating. $\mathrm{pH}$ was measured at the beginning of incubation and then after 4 and 8 weeks of incubation. Aliquots of liquid cultures were stored in $-20{ }^{\circ} \mathrm{C}$ for use in subsequent microbial analyses.

After 8 weeks of incubation, all coupons were removed from the test bottles. Shortly after removal, a gentle stream of sterile MilliQ water was run over the coupons to remove any planktonic cells from the biofilms. Pictures of the coupons were then taken. Certain coupon biofilms/corrosion products were examined by scanning electron microscopy (SEM), X-ray powder diffractometery (XRD) or energy-dispersive X-ray spectroscopy (EDS). For these, sterile MilliQ water was used to gently wash the coupons three times, after which they were air-dried in a physical containment level 2 cabinet for $2 \mathrm{~h}$ and then stored in a desiccator. For SEM of coupon biofilms, one coupon per test condition underwent fixation with glutaraldehyde solution ( $2.5 \mathrm{vol} \%)$ then dehydration via an ethanol series $(25 \%, 50 \%, 75 \%, 90 \%$ and $100 \%)$ [40]. Coupons for steel surface analyses (SEM, 3D optical profilometery, weight loss), underwent a series of cleaning steps to remove biofilms/corrosion products. Individual coupons were sonicated in sterile MilliQ water for $2 \mathrm{~min}$ (the fluid from this was stored at $-20^{\circ} \mathrm{C}$ for subsequent microbial analyses), then in Clark's solution [41] for $2 \mathrm{~min}$, followed by rinsing with water and ethanol, drying under warm airflow and then storing in a desiccator.

\subsection{Metal Coupon and Microbial Analysis}

SEM (Zeiss SUPRA 40VP-25-38, Oberkochen, Germany) images were taken of the biofilms and the steel surfaces of separate fixed and cleaned coupons for each of the test conditions using a range of magnifications $(150 \times$ to $12,000 \times)$. One coupon from each of the six treatments was used for EDS (Zeiss SUPRA 40VP-25-38, Oberkochen, Germany and INCA software, version 4.13) to provide semi-quantitative analyses of the biofilms/corrosion products formed on the coupons. Intensity with weight percent (wt.\%) of chemical elements was averaged from two locations of the biofilm on each coupon surface. One uncleaned coupon from each of the six treatments was used for XRD (Bruker D8 Advance, Germany). Compositions of surface products were scanned with a copper line focus $\mathrm{X}$-ray tube producing $\mathrm{K} \alpha$ radiation from a generator operating at $40 \mathrm{kV}$ and $30 \mathrm{~mA}$. 
Three cleaned coupons from each of the six treatments were used to obtain average corrosion rates via weight loss using the method described in reference [41]. These coupons were also used for 3D optical profiling (Bruker Contour GT-K1) to obtain quantitative information about corrosion morphology. Each metal coupon was scanned over the entire surface (using $5 \times$ objective), and any areas with localised pitting were subjected to more detailed, higher resolution analysis. Pit depth $(\mu \mathrm{m})$ and relative volume $\left(\mu \mathrm{m}^{3}\right)$ for pits greater than $10 \mu \mathrm{m}$ depth were recorded and analysed using VISION 64 ${ }^{\mathrm{TM}}$ software (Bruker), and then pit density was calculated by number of $\mathrm{pit} / \mathrm{mm}^{2}$.

For corrosion morphology analysis, the pitting depth, relative pit volume and corrosion rates were statistically compared for significant differences among the treatments $(p<0.05)$ using one-way ANOVA and Tukey's post-hoc test $\left(\right.$ IBM $^{\circledR}$ SPSS $^{\text {TM }}$ Statistics version 25).

Microbial analysis was based on agar plate counts and 16S rRNA gene metabarcoding. Relative abundance was determined by a sum of the aerobic and anaerobic counts from the liquid in each treatment. For metabarcoding, liquid samples of T2, T4 and T5 experiments (Table 1) obtained at week 2 and week 8, together with biofilm suspensions obtained following sonication from week 8 samples were sent to a commercial test facility (AGRF, Adelaide, Australia) for DNA extraction and Illumina MiSeq sequencing. The primer pairs used were 341F (CCTAYGGGRBGCASCAG) and 806R (GGACTACNNGGGTATCTAAT) for amplification of the V3-V4 region of $16 \mathrm{~S}$ rRNA genes. Data were processed using Quantitative Insights Into Microbial Ecology (QIIME 1.9) followed by METAGENassist [36].

\section{Results}

\subsection{Surfaces of Coupons Before Cleaning}

Photos of coupon surfaces were taken directly after removal from the test solution at the end of the 8-week immersion period (see Figure 1). The T1 and T3 test condition coupons had orange and black corrosion products on the surfaces, the T4 coupons were relatively free of corrosion products and black films were present on the remaining treatments (i.e., T2, T5 and T6).

The surfaces of individual test replicate coupons set aside for biofilm/corrosion product examination were observed using the SEM (Figure 2), and analysed by EDS (Figure 3). The coupon from the uninoculated test (T1) was covered in a general corrosion product, which appears to be a form of iron oxide. The images of the coupon exposed to the orange tubercle biofilm inoculum (T2) showed a biofilm present, with phosphorus and a relatively high sulfur content detected by the EDS (Figure 3). The coupon from the D. desulfuricans inoculum under aerobic incubation (T3) visually had a thicker biofilm on the surface compared to the coupon from the $D$. desulfuricans inoculum under anaerobic incubation (T6) (Figure 2). The biofilm of the T3 coupon also had much more sulfur present (relative to iron) compared to the T6 coupon, according to EDS (Figure 3). For the defined mixed microbial species tests (T4 and T5), the consortia including D. desulfuricans (T5) visually had a much denser biofilm compared to the sparse biofilm of T4 (Figure 2). No sulfur was detected in the mixed consortia without D. desulfuricans (T4) (Figure 3), while a small amount of sulfur in the biofilm was detected in the defined microbial consortia when the D. desulfuricans were present (T5) (Figure 3). The iron:sulfur ratios shown in Figure 3 provide an indication of the relative amount of sulfur detected in surface product analysis. 


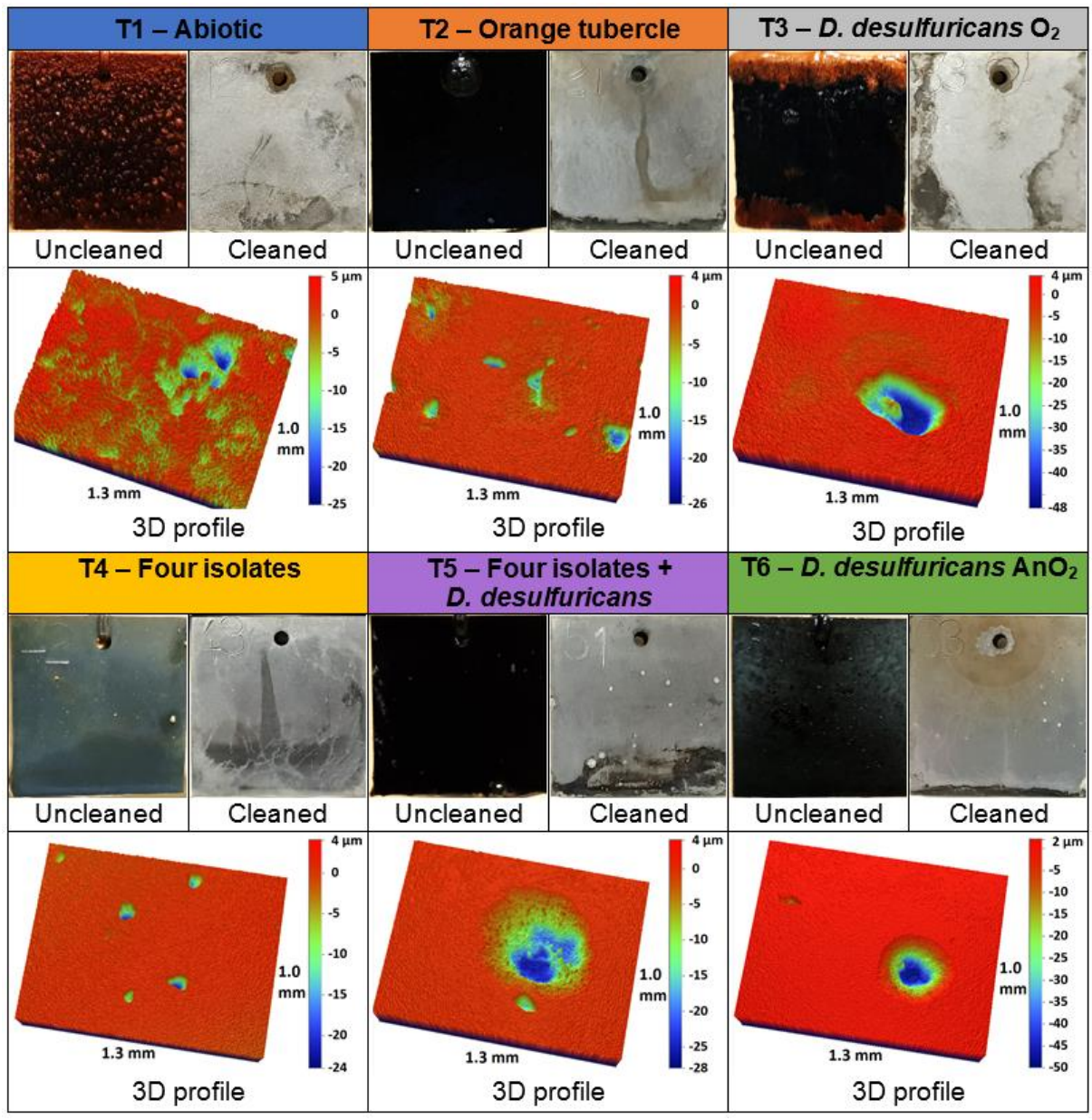

Figure 1. Photos of uncleaned and cleaned coupons after 8-weeks immersion in half-strength marine broth for the six different microbial testing conditions, together with 3D surface profiles of cleaned coupons showing surface and pit morphology.

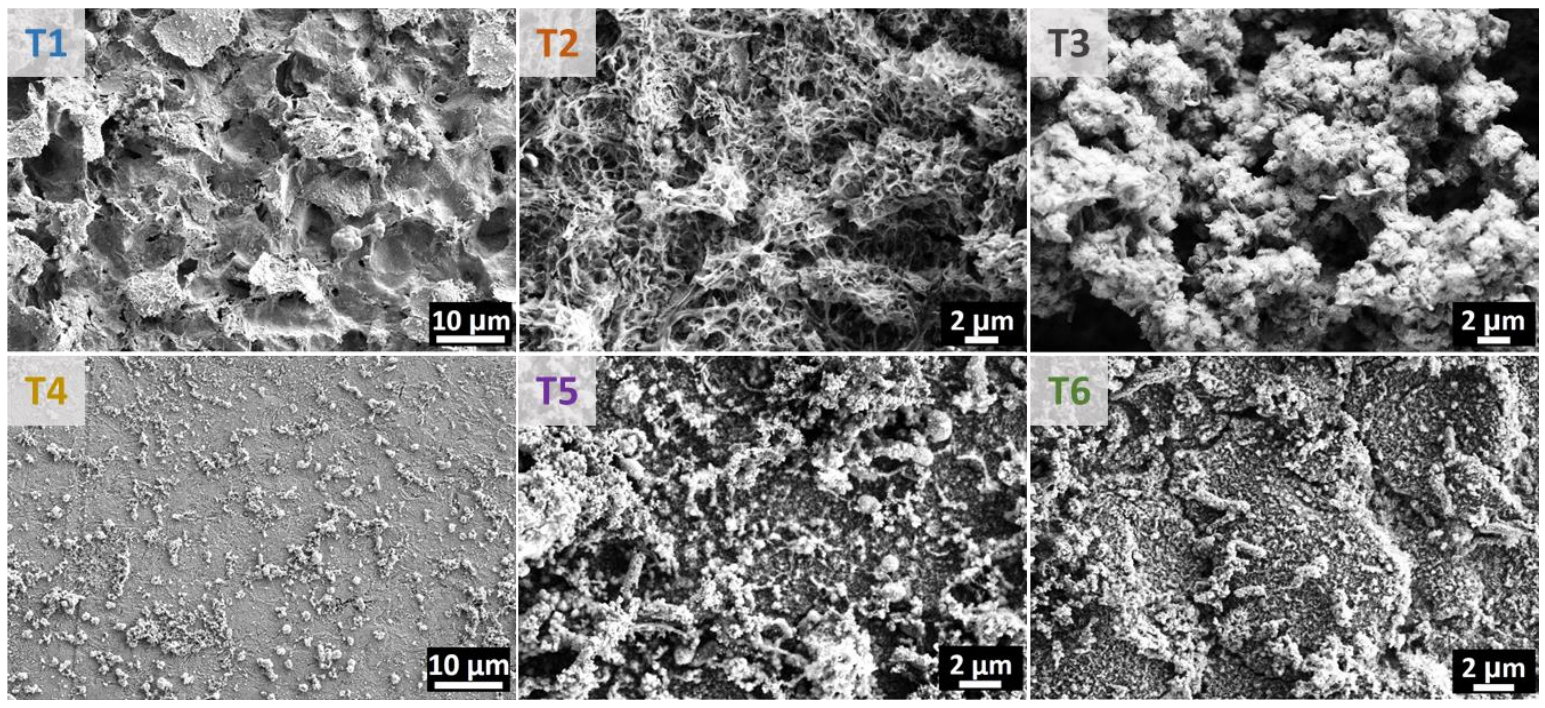

Figure 2. SEM images of biofilms/corrosion products on surfaces of coupons tested after 8-weeks incubation in the six different test conditions. All of these coupons underwent fixation (dehydration and $2 \%$ glutaraldehyde immersion) prior to imaging. 


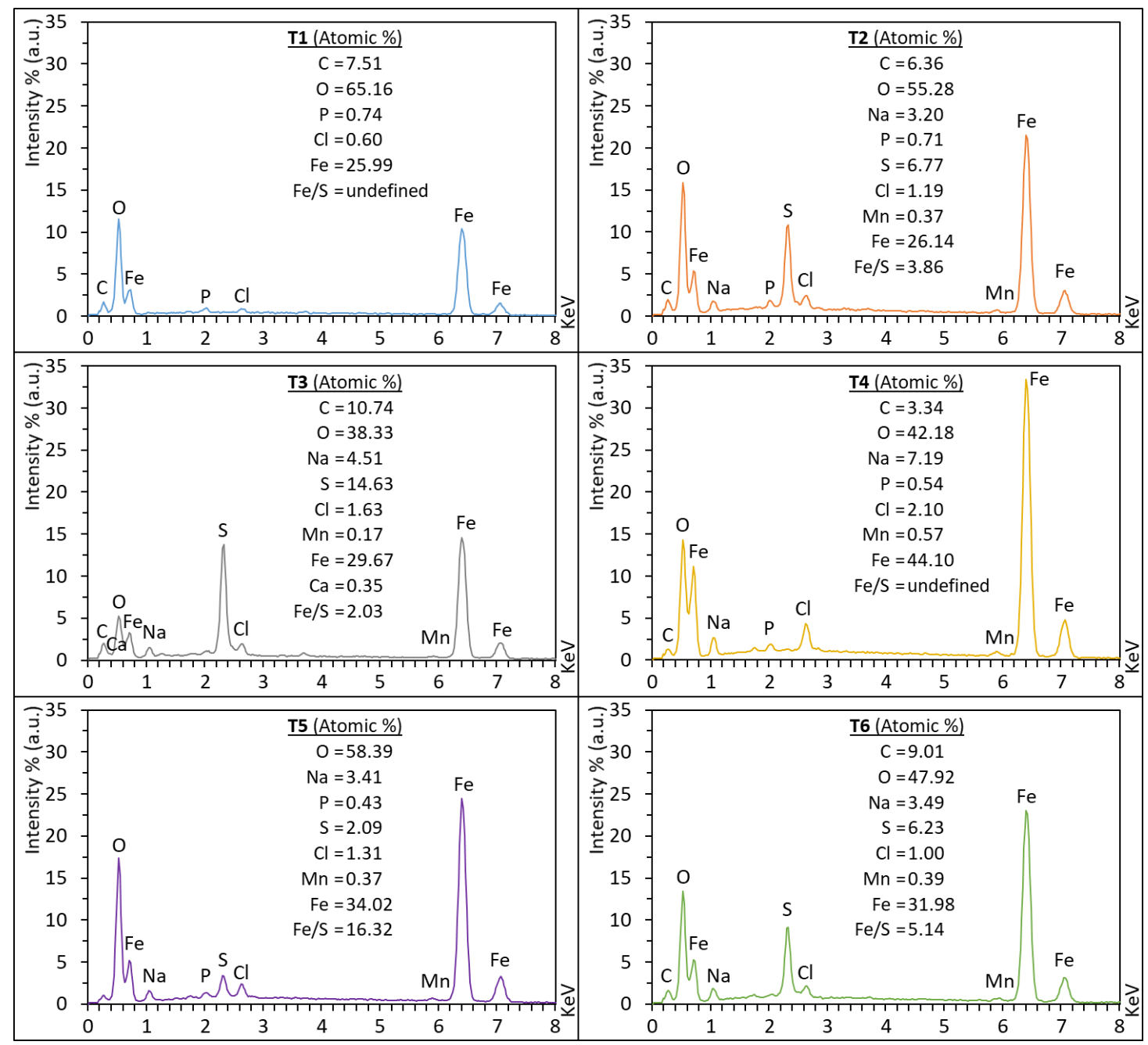

Figure 3. EDS spectra of the biofilms/corrosion products formed on DH36 coupons tested in the six different treatments after 8-week incubation.

The XRD spectra peaks of individual phases were identified by comparing the diffraction pattern to a known standard from the diffraction powder database of the International Centre for Diffraction Data (Diffrac Eva software, version 4.1). Unfortunately, the XRD spectra obtained (Figure S1) provided ambiguous results for corrosion products/biofilms, with the three peaks observed in each scan matching that of iron. It is possible that the intensity of iron dominated the scanning spectra or that the corrosion products formed were amorphous in nature.

\subsection{Corrosion Evaluation}

Example photos of the surfaces of test coupons after removing any biofilms and corrosion products are shown in Figure 1. The key difference observed was that while the uninoculated samples (T1) showed signs of general corrosion and occasional pitting, most of the coupons tested in different biotic conditions appeared to suffer from sparse localised pitting corrosion. SEM scans of the cleaned surfaces (Figure 4) confirmed that the uninoculated control (T1) coupon had a combination of general and localised corrosion attack, as did the coupon tested in the D. desulfuricans aerobic test configuration (T3). The coupons from the other tests (T2, T4, T5 and T6) contained localised corrosion but were relatively free from general corrosion. Finally, the diameters of pits observed for coupons tested with $D$. desulfuricans (T3, T5 and T6) appeared to be generally larger than those for the other test configurations. 

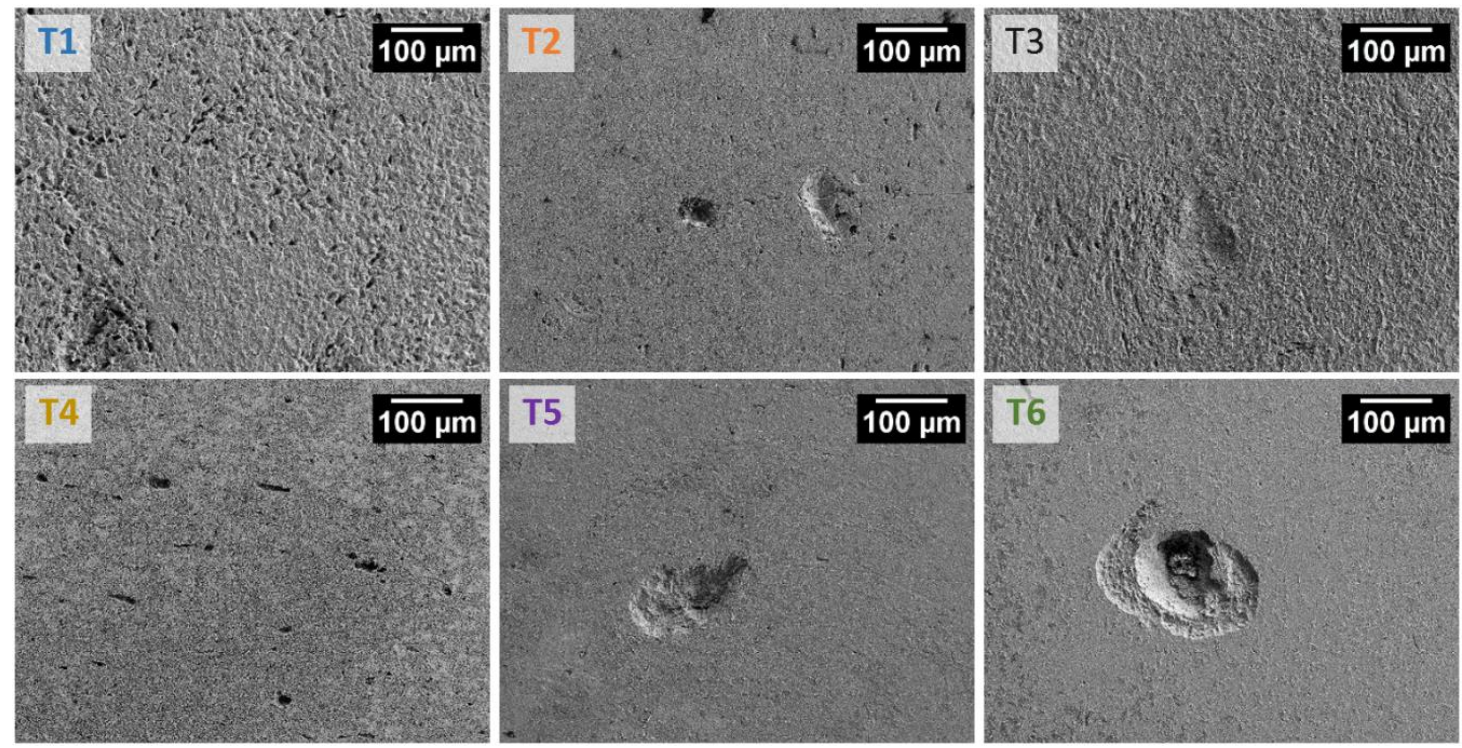

Figure 4. SEM images of surfaces of cleaned test coupons after 8-week immersion in the six different test conditions.

To further characterise the morphology of localised corrosion, 3D optical profiling was performed on one side of one of the cleaned coupons for each test condition (see examples in Figure 1). The pit density, which was calculated for all treatments based on the number of pits $(>10 \mu \mathrm{m})$ per $\mathrm{mm}^{2}$, was $\sim 2$ (pit $/ \mathrm{mm}^{2}$ ) for $\mathrm{T} 1$, (uninoculated treatment), and $\mathrm{T} 2$, T4 and T5 (mixed consortia inoculum), and $\sim 1\left(\mathrm{pit} / \mathrm{mm}^{2}\right.$ ) for T3 and T6 (D. desulfuricans alone). The coupons with the largest pits were from tests containing D. desulfuricans (T3, T5 and T6, see details in Figure 5). Apart from the coupon from T4 (four isolates) which had one pit deeper than $30 \mu \mathrm{m}$, only the coupons from tests with $D$. desulfuricans (T3 and T6) had any pits greater than $30 \mu \mathrm{m}$ depth (five and six pits, respectively). The deepest pit found was $50.2 \mu \mathrm{m}$ for the coupon tested in $D$. desulfuricans under anaerobic conditions (T6), compared to $27 \mu \mathrm{m}$ for the deepest pit for the uninoculated control (T1). The average pit volumes (of five deepest pits) were nearly an order of magnitude greater for the tests containing D. desulfuricans (T3, T5 and T6) compared to the tests lacking D. desulfuricans.

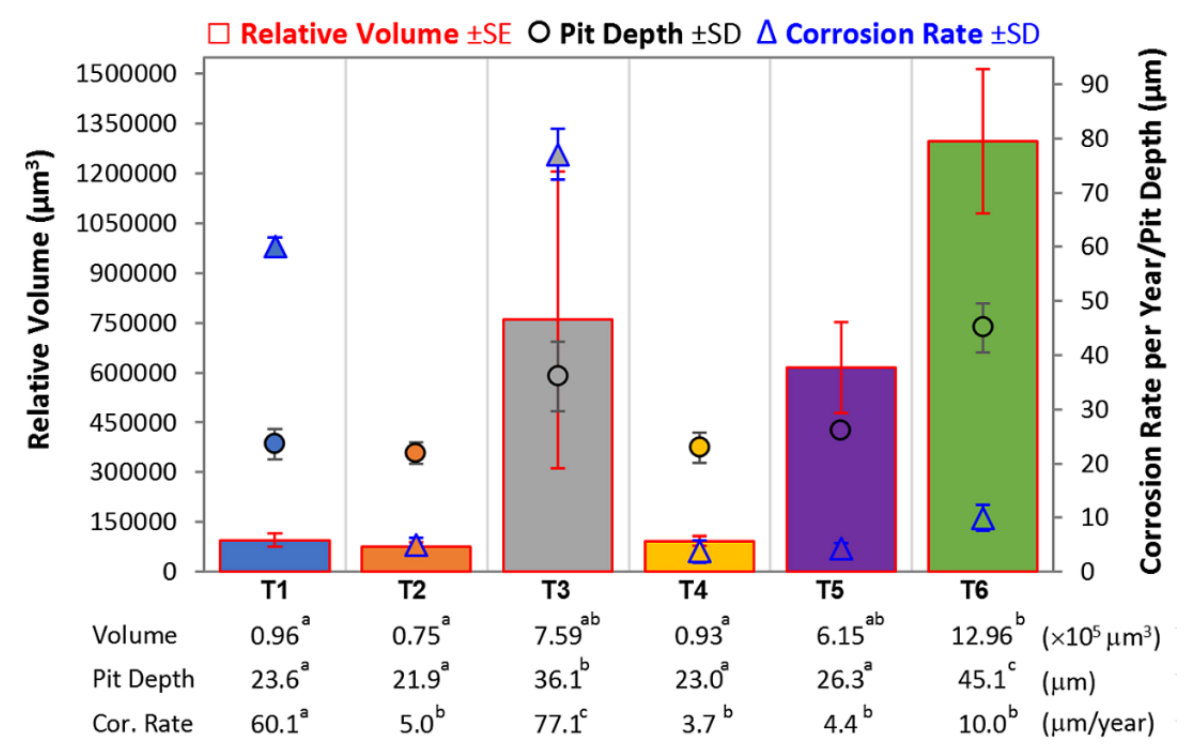

Figure 5. Summary of the corrosion attack on steel samples from the six different treatments. Averages of 5 highest values of relative volume and pit depth as well as average corrosion rate are shown with statistical analyses. Significant differences $(p<0.05)$ were shown by different series of superscript letters on each parameter. 
The average corrosion rates of the DH36 coupons after 8 weeks of incubation in the different test scenarios were determined via mass loss (Figure 5). The highest corrosion rates among the six treatments obtained $(p<0.05)$ were for the T3 $(D$. desulfuricans tested aerobically) and T1 (uninoculated) test conditions. For all the other test conditions very low average corrosion rates were measured; always much less than the uninoculated control, indicating a form of corrosion inhibition. Given that the localised attack of the uninoculated control (T1) was relatively minor, the relatively high weight loss for this test condition will have been dominated by general/uniform corrosion.

\subsection{Test Solutions}

Over the 8-week duration of the corrosion tests, the colours of the test solutions changed (see Figure 6), which is a potential indication of the metabolic and corrosion processes that took place. Of particular interest was the general blackening of solutions for tests T2 (orange tubercle inoculum), T5 (four isolates $+D$. desulfuricans aerobic) and T6 (D. desulfuricans anaerobic), and the black precipitation layer observed at the bottom of test condition T3 (D. desulfuricans aerobic). This blackening might be an indication of sulfate reduction and $\mathrm{FeS}$ production.

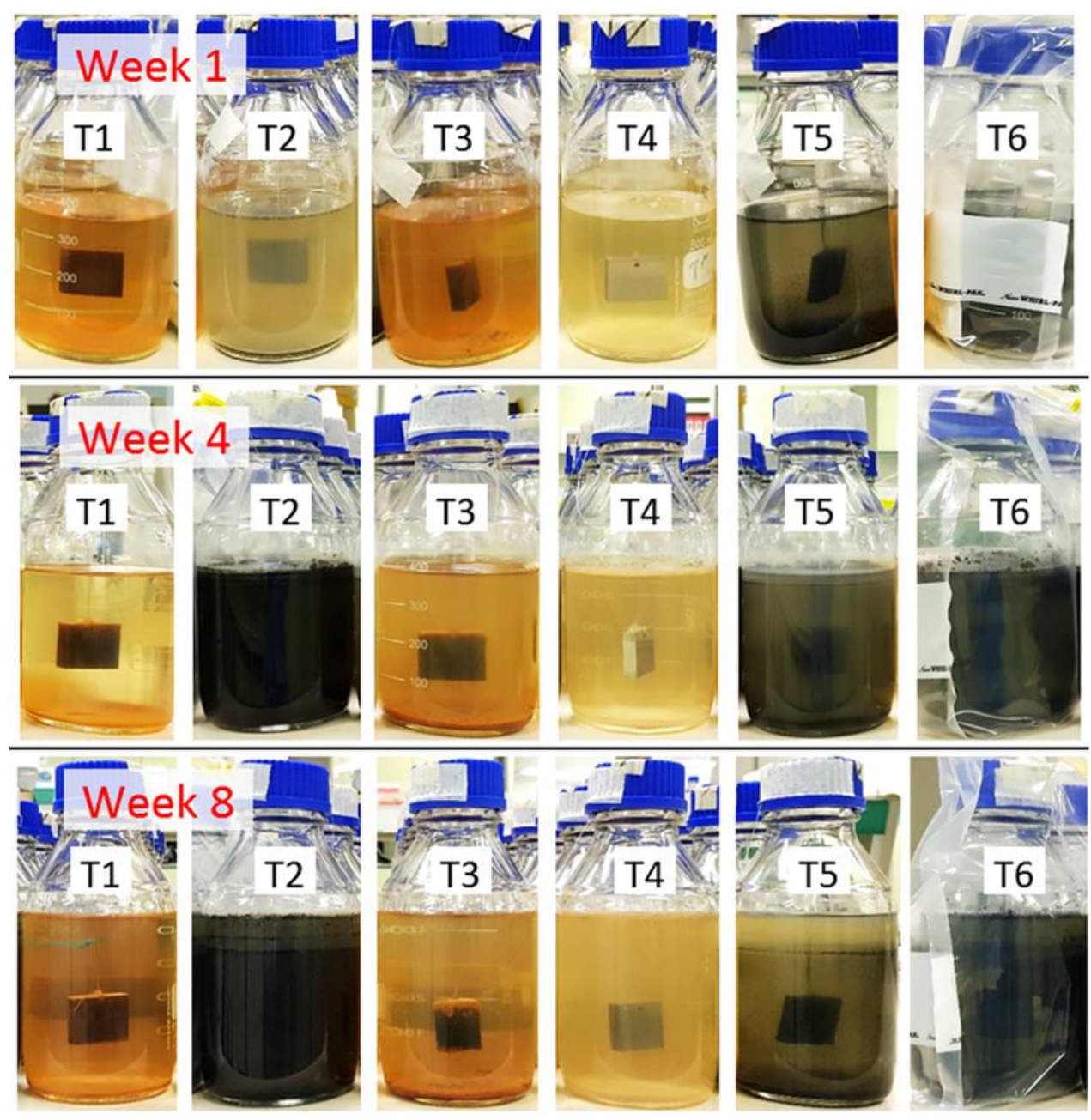

Figure 6. Changes in appearance of test bottles of six treatments during 8 weeks of immersion.

In general, the $\mathrm{pH}$ values of the solutions (Table 2) were reasonably constant for all of the test conditions over the 8-week incubation period, with $\mathrm{pH}$ values staying within \pm 0.5 of the initial value of 7.54 . The greatest changes observed were for $\mathrm{T} 4$, which went slightly more basic to 7.9, and T6 which went slightly more acidic to just below 7.0. 
Table 2. Bacterial counts and $\mathrm{pH}$ during 8-week incubation test of six treatments (Table 1). Initial $\mathrm{pH}$ of sterile media before inoculation was $\sim 7.54$. Total plate count in each treatment was the sum of both aerobic and anaerobic counts on marine agar (MA) and tryptic soy agar $\left(\mathrm{TSA}^{+}\right)$media, respectively.

\begin{tabular}{lcccccc}
\hline \multirow{2}{*}{ Test (T1-T5: $\mathbf{O}_{\mathbf{2}} ; \mathbf{T 6}$ 6: $\mathbf{A n O}_{2}$ ) } & \multicolumn{3}{c}{ Total Bacterial Plate Count (cfu/mL) } & \multicolumn{2}{c}{ pH Measurement } \\
\cline { 2 - 7 } & Initial & Week 2 & Week 4 & Week 8 & Week 4 & Week 8 \\
\hline T1 (uninoculated) & - & - & - & - & $7.58 \pm 0.02$ & $7.55 \pm 0.02$ \\
T2 (orange tubercle) & $\geq 10^{5}$ & $10^{7}-10^{8}$ & $1 \times 10^{8}$ & $10^{8}-10^{9}$ & $7.47 \pm 0.03$ & $7.32 \pm 0.06$ \\
T3 (D. desulfuricans) & $2 \times 10^{6}$ & $7 \times 10^{5}$ & $2 \times 10^{6}$ & $10^{3}-10^{4}$ & $7.56 \pm 0.04$ & $7.73 \pm 0.10$ \\
T4 (Four isolates) & $4 \times 10^{6}$ & $4 \times 10^{7}$ & $6 \times 10^{7}$ & $9 \times 10^{7}$ & $7.74 \pm 0.05$ & $7.90 \pm 0.06$ \\
T5 (Four isolates & $6 \times 10^{6}$ & $3 \times 10^{7}$ & $1 \times 10^{8}$ & $10^{6}-10^{7}$ & $7.32 \pm 0.04$ & $7.42 \pm 0.06$ \\
D. desulfuricans) & $2 \times 10^{6}$ & $5 \times 10^{7}$ & $5 \times 10^{7}$ & $10^{4}-10^{5}$ & $6.98 \pm 0.10$ & $6.98 \pm 0.09$ \\
T6 (D. desulfuricans) & & & & &
\end{tabular}

\subsection{Analysis of Microbial Populations}

Total plate count results are provided in Table 2. While a reduction in counts for the D. desulfuricans inoculum tests (T3 and T6) was seen between the start and the end of the tests, in general the microbial populations were reasonably constant throughout incubation times. It is also worth noting that no colonies were observed in the aerobic plate tests for D. desulfuricans alone treatments (T3 and T6), suggesting that these solutions were free of any aerobic microbial contamination.

Figure 7 summarises the metabarcoding analysis of the mixed microbial consortium treatments (i.e., T2, T4 and T5) at week 2 (planktonic) and week 8 (planktonic and biofilm). The solution inoculated with the orange tubercle (T2) has, as expected, the most diverse community. While there were few bacterial taxa that reduced in relative abundance in the T2 solution during the test (e.g., Exiguobacterium spp. dropped from $13 \%$ to $3 \%$ in planktonic phase from 2 to 8 weeks), many bacteria maintained their presence in both planktonic and biofilm phases (e.g., Clostridiales and Rhizobiales). However, several bacteria were only detected after 8 weeks including Desulfarculus baarsii, Desulfosporosinus spp. and Thioalkalivibrio sp. Reasonable differences can also be seen between the planktonic and biofilm phases of the T2 solution at 8 weeks (e.g., Rhodobacteraceae spp. and Clostridium thiosulfatireducens more abundant in the biofilm phase).

The metabarcoding results for the combinations of isolates (T4 and T5) identified all of the bacteria inoculated in each test configuration in at least one of the time/phases tested. For both of these test configurations the proportion of $P$. bellariivorans tended to decrease from week 2 to week 8 , and $H$. korlensis was only ever found in any reasonable level in the biofilm phase. A key difference between the two test configurations was for B. aquimaris, which had a strong presence in the T4 liquid (four isolates) but was only detected at low levels in the T5 liquid (four isolates $+D$. desulfuricans). S. pontiacus was detected at reasonably consistent levels for both test solution types throughout the tests and in both the planktonic and biofilm phases.

The metabarcoding data were further analysed for putative functions using METAGENassist to interpret microbial metabolism and other traits, the results of which are presented in Table S2. Key aspects of the sulfur cycle, including sulfate reduction (detected at high levels in all samples at week 8) and sulfur oxidation (for the orange tubercle configuration at week 8) were detected. 


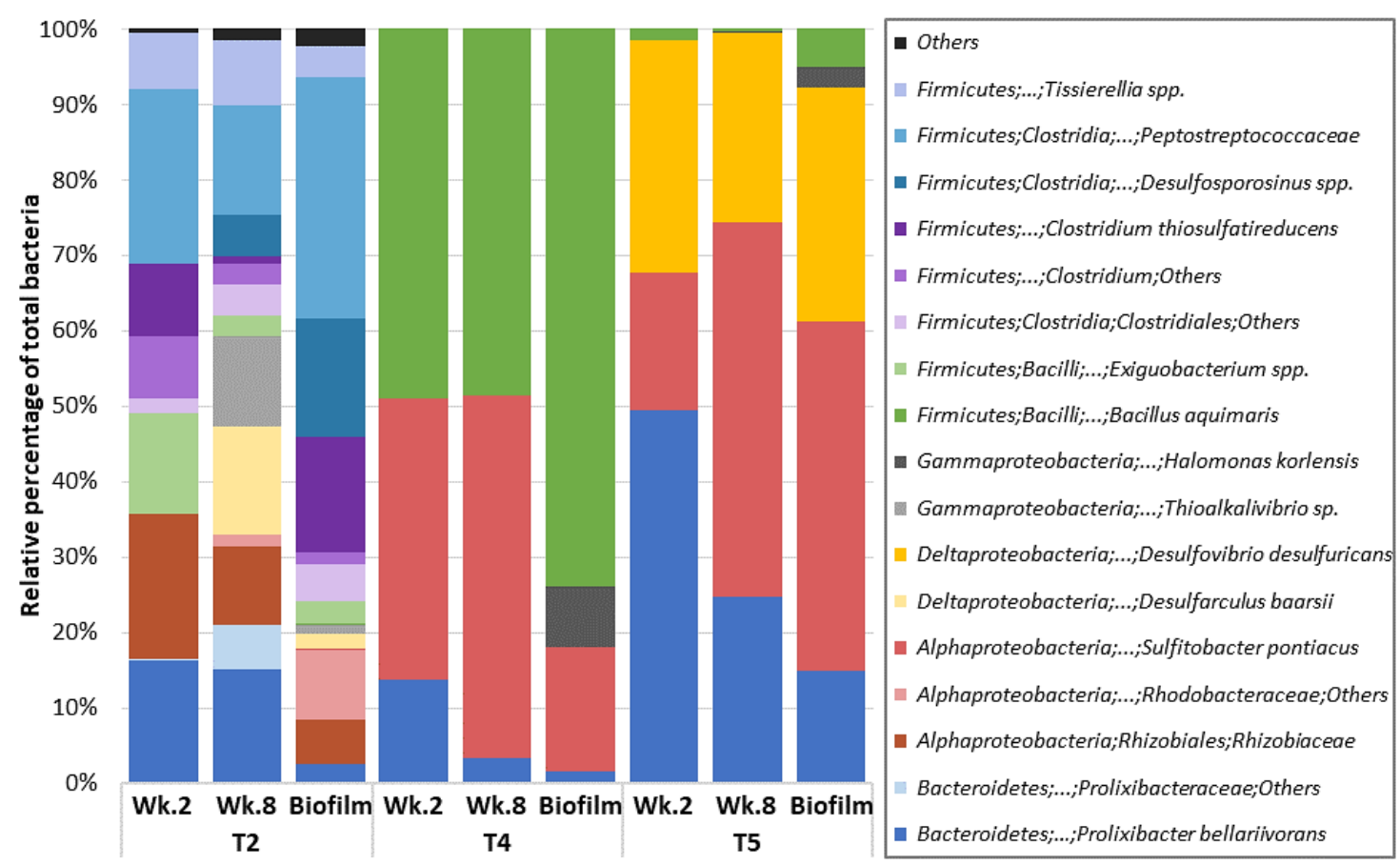

Figure 7. Microbial communities identified by $16 \mathrm{~S}$ rRNA gene metabarcoding of mixed consortium treatments (T2, T4 and T5), for planktonic communities (at weeks 2 and 8 ) and for the attached biofilms obtained by sonication (at week 8).

\section{Discussion}

\subsection{Surfaces of Coupons Before Cleaning}

The black corrosion products on the surfaces and sulfur detected in the biofilms (by EDS) of coupons from several treatments (T2, T3, T5 and T6) indicates iron sulfide production, and active sulfate reduction. This matches well with the presence of $D$. desulfuricans, when specifically added to the tests (i.e., T3, T5 and T6) and the relatively high potential for sulfate reduction determined from the METAGENassist analysis of the T2 orange tubercle inoculum. The iron:sulfur ratios calculated for the biofilms indicated that the highest to lowest relative amounts of sulfur detected were for T3 $>\mathrm{T} 2>\mathrm{T} 6>\mathrm{T} 5$, which qualitatively matches the thicknesses of the biofilms observed in SEM images.

One somewhat unexpected observation was that the nominally aerobic test with the D. desulfuricans (T3) produced a visually thicker biofilm than that for the corresponding anaerobic test with $D$. desulfuricans (T6). While they are more commonly known as strict anaerobes, many sulfate-reducing bacteria, including the culture collection strain used in this work, can survive/grow in aerobic environments [42,43]. It is also possible that the visually thicker biofilm observed for the $D$. desulfuricans aerobic incubation (T3) is a result of a stress response by the bacteria. Although the aerobic tests (including the T3 treatment) were nominally aerobic at the start of the tests it is likely that the oxygen concentration in the solutions dropped over time due to microbial oxygen consumption, making the environment more suitable for optimal growth of $D$. desulfuricans. A suggestion for future work would be to monitor the oxygen concentration in the solutions as a function of time.

\subsection{Corrosion Attack}

Coupon weight loss indicates that T1 (uninoculated) and T3 (D. desulfuricans aerobic) treatments demonstrated greater general corrosion attack than the other treatments. However, T6 (D. desulfuricans anaerobic), T3 (D. desulfuricans aerobic) and T5 (four isolates $+D$. desulfuricans aerobic) treatments had significantly greater localised pitting than the other treatments. The pitting results for $D$. desulfuricans anaerobic incubation (T3) (average pit depth $45 \mu \mathrm{m}$ ) were greater than for previous tests for the same bacterial strain using a modified Baar's medium (average pit depth $\sim 27 \mu \mathrm{m}$ ) with the same steel type [32]. However, 
the corresponding weight loss data for the previous modified Baar's medium tests with $D$. desulfuricans were much greater ( $\sim 80 \mu \mathrm{m} /$ year) than obtained in this work $(10 \mu \mathrm{m} /$ year $)$. It is important to note that in addition to pitting, general corrosion of the steel surface was observed in the previous study. This indicates that test medium used can have an impact on steel corrosion and pitting outcomes. Previous work indicated that the addition of Fe ions/lactate to modified Baar's medium can have a significant effect on the weight loss results, which are indicative of any general corrosion taking place [40]. No addition of Fe ions to the bulk test solutions was performed in the current work.

The main hypothesis for the work was that a consortium of microbes would result in greater corrosion rates than single isolates (T3 and T6) or an uninoculated control (T1). This was because a range of phenotypes were considered important in promoting ALWC. The consortium tests (T2, T4 and T5) actually showed the three lowest weight losses (typically indicative of general corrosion) of all of the tests performed. Microbial corrosion (including ALWC), however, is more often linked to localised rather than general/uniform corrosion. In relation to localised corrosion, the average pit depths were smaller for the consortia treatments (T2, T4 and T5) than for sole D. desulfuricans tests (T3 and T6). The volume of pits for the $\mathrm{T} 5$ treatment (four isolates $+D$. desulfuricans) were similar to the sole $D$. desulfuricans tests (T3 and T6), which were much greater than for any of the other test treatments.

One possible reason for the lower levels of corrosion obtained for the mixed microbial communities compared to the uninoculated control or single $D$. desulfuricans tests was that the types of microbes present (orange tubercle, T2) or chosen (pure cultures) were inappropriate for ALWC. The orange tubercle inoculum (T2), was taken from a site which had pitting corrosion and diagnosed ALWC beneath the orange tubercle. Thus, this orange tubercle consortium should have been appropriate to generate optimal ALWC conditions in our laboratory tests. Indeed, we previously found increased corrosion when orange tubercles (taken from another site with suspected ALWC) were used as inocula in laboratory tests, compared to an uninoculated control test [25]. The metabarcoding analysis of T2 identified several microbes present in both the biofilm and planktonic phases that were capable of sulfate reduction (more detail below) and sulfur was clearly identified in the biofilm by EDS.

High corrosion rates of $\sim 100-125 \mu \mathrm{m} /$ year (from weight loss) were previously [25] found for tests with orange tubercle inocula compared to $\sim 40 \mu \mathrm{m} /$ year in uninoculated controls when using a similar test arrangement (e.g., steel type, test duration) to that used in the current work. These previous higher corrosion rates were observed for samples with uniform corrosion across sample surfaces and with little localised corrosion. Two obvious key differences between the previous [25] and current studies were the initial microbial community structure of the inocula and the types of nutrients added to the test solutions. While a Deltaproteobacteria SRB (Desulfarculus baarsii) was detected in the orange tubercle inoculum (T2) test, this strain has not typically been linked to corrosion. In the previous study [25], an unidentified species from the Desulfobulbaceae family of Deltaproteobacteria was found at reasonably high levels (up to $\sim 40 \%$ ) in the planktonic phase. This family includes Desulfopila corrodens which was directly linked to rapid corrosion in ALWC studies [23].

Glucose (a carbon and electron donor source) and yeast extract were components of the earlier test medium [25], while peptone and yeast extract were present in relatively low amounts in the current work's medium. It has been shown that the types of nutrients available for microbial growth and the physicochemical conditions can have substantial effects on the composition of microbial communities that ensue (e.g., [44,45]). These two features likely explain the microbial differences observed between the earlier [25] and the current research. Additionally, changes in the level of carbon sources present in test media can affect the extent of corrosion caused by a single SRB strain (e.g., [29]).

The majority of microbes chosen for the defined consortium tests survived in reasonable numbers throughout the test period, although there were some clear changes in the microbial species composition over the test duration (discussed in more detail below). 
There was also clear evidence of sulfate reduction, as seen by the black solution and presence of sulfur in the biofilm for the defined mixed microbial treatment, which included $D$. desulfuricans (T5), indicating that $D$. desulfuricans were metabolically active. As discussed above, it is possible that relatively low levels of carbon sources/electron donors in the test media may have altered physicochemical processes (i.e., sulfate reduction) that play a role in microbial corrosion and had an effect on corrosion rates.

There have been varying reports on the effect of the presence of different species of Bacillus on corrosion with some indicating increased corrosion [46-48] and others showing corrosion inhibition [49-53]. Both defined mixed microbial treatments, with (T5) or without (T4) D. desulfuricans, had similar levels of general corrosion but qualitatively different biofilm thicknesses, where T5 was greater than T4 (Figures 1 and 2). The 16S rRNA gene metabarcoding showed very different relative amounts of B. aquimaris. T5 had a lower general corrosion level than either of the tests with D. desulfuricans alone (T3 and T6), indicating that the additional microbes reduced the corrosion mediated by $D$. desulfuricans. This could indicate corrosion inhibition, perhaps due to competition for substrates among the added pure cultures.

\subsection{Analysis of Microbial Populations}

Although the $D$. desulfuricans strain used is a facultative anaerobe, plate counts showed that there were still reasonable numbers $\left(10^{3}-10^{4} \mathrm{cfu} / \mathrm{mL}\right)$ of viable $D$. desulfuricans present in solutions after 8 weeks when tested in nominally aerobic test conditions. The presence of sulfur in the biofilms of the coupons from these tests (e.g., T3) indicated that $D$. desulfuricans were metabolically active despite the possible presence of oxygen in the bulk solution. Metabarcoding analysis of the planktonic and biofilm phases of the defined consortium including $D$. desulfuricans (T5) showed a relatively high abundance of $D$. desulfuricans throughout this nominally aerobic test. Given the specific inclusion of aerobic microbes in T5 it is highly likely that they used the available oxygen creating anaerobic conditions, which are optimal for the growth of $D$. desulfuricans. This is important as it shows how testing with microbial consortia can produce an environment conducive to anaerobic microbes such as $D$. desulfuricans in a more natural way rather than by exogenously producing low oxygen levels by means such as nitrogen purging. There have been some reports on the potentially important role of oxygen in MIC of SRB [22,54-57] and of other microbes [58,59]. In any case, results from the current work support further studies on this topic.

The microbial consortium composition in the orange tubercle inoculum test (T2) differed over time in the planktonic phase (between 2 weeks and 8 weeks) and also between the planktonic and biofilm phases at 8 weeks. This is expected as the environmental conditions in the laboratory test was quite different to the tubercle's native location. The nature of the community succession will be different in the planktonic and biofilm phases as there will be local differences in oxygen content and corrosion products from the carbon steel could act as a nutrient source for certain microbes $[6,60]$.

At 8 weeks incubation both planktonic and biofilm phases in T2 contained microbes potentially capable of sulfide/sulfur oxidation (e.g., Thioalkalivibrio sp.) and sulfate reduction (e.g., Desulfosporosinus spp. and D. baarsii). A combination of both sulfur oxidisers and sulfate reducers could form a closed sulfur cycle, which has previously been reported to potentially lead to rapid corrosion [5,8,13-17]. However, extensive corrosion was not seen in T2. It is possible that the system may have needed more time to develop an active corrosion state. Although strains of the Deltaproteobacteria (including D. desulfuricans) are the most commonly regarded sulfate reducers, other microbial groups also are capable for sulfate reduction. These include Desulfosporosinus spp., which is a member of the Firmicutes phylum. Various microbes relevant to the nitrogen cycle (e.g., nitrogen fixation, nitrite reduction and ammonia oxidation) were identified in the liquid and biofilm of T2 at 8 weeks. Nitrifying bacteria are important as they can potentially produce fixed nitrogen that is used to support/maintain the growth of anaerobic bacteria such as SRB [14]. However, conditions would need to be aerobic to support their nitrifying phenotype. 
A number of interesting spatio-temporal changes were observed in the microbial communities of the defined consortia tests (T4 without and T5 with D. desulfuricans). Although H. korlensis comprised a reasonable proportion of the initial inoculum in both T4 and T5 ( $7 \%$ and $5 \%$, respectively), this bacterium was only detected in relatively small relative abundances in the biofilm phase at week $8(<10 \%$ of total). This might suggest a preference for biofilm growth. Large differences were seen in the numbers of B. aquimaris present in the $\mathrm{T} 4$ and $\mathrm{T} 5$ treatments. It was the most abundant bacterium in both the planktonic phase and biofilms in T4, but it was only found in low abundances in T5. No explanation could be suggested for these differences, but since the presence of $D$. desulfuricans was the only difference, this could point to some interaction. P. bellariivorans made up $\sim 1 \%$ of the initial inoculum according to viable cell counts, but it was quite abundant in T5 when in combination with the $D$. desulfuricans relative to its abundance without $D$. desulfuricans in T4. In T5, P. bellariivorans was more abundant than B. aquimaris or H. korlensis according to metabarcoding at weeks 2 and 8; despite that both of these latter bacteria comprised more cells in the initial inoculum relative to P. bellariivorans. These observed changes show how it is difficult to predict the species development in mixed consortia tests, which is likely to be affected by numerous factors including the test medium composition and physicochemical conditions. An increasing number of reports are starting to be produced investigating the development of multispecies biofilms (e.g., [61] and the references in Table S1). It will be interesting to keep a track of the development of this area of research and see what additional insights it might be able to provide microbial corrosion research.

The overall aim of this work was to investigate whether defined microbial species communities could be used to generate conditions conducive to the rapid corrosion of steel, similar to what occurs in ALWC in the marine environment. Notable differences in the biofilms and the microbial consortia were observed for the treatments tested. Lower uniform corrosion and weight loss were recorded for treatments with multispecies communities, however, the results for localised corrosion (typically more indicative of microbial corrosion) were not as straightforward, with one of the multispecies treatments (the defined consortium with $D$. desulfuricans) producing large sized pitting while another (orange tubercle inoculum) had much lower localised corrosion. Table 3 has been provided to help summarise some of the main observations of the work undertaken.

Table 3. Summary of observations from corrosion experiments using a variety of test conditions. Colours of cells have been used to highlight related results observed in different test conditions.

\begin{tabular}{|c|c|}
\hline Test (Inoculum, Aeration Status) & Comments \\
\hline \multirow{2}{*}{ T1 (uninoculated, aerobic) } & Oxygen in solution led to general corrosion \\
\hline & Some localised corrosion but with relatively low volumes \\
\hline \multirow{3}{*}{ T2 (orange tubercle, aerobic) } & Aerobic bacteria likely utilised oxygen and reduced general corrosion \\
\hline & SRB present, sulfate reduction suspected \\
\hline & Some localised corrosion but with relatively low volumes \\
\hline \multirow{3}{*}{ T3 (D. desulfuricans, aerobic) } & Oxygen in solution led to general corrosion \\
\hline & SRB present, sulfate reduction suspected \\
\hline & Localised corrosion with relatively high volumes \\
\hline \multirow{2}{*}{ T4 (Four isolates, aerobic) } & Aerobic bacteria likely utilised oxygen and reduced general corrosion \\
\hline & Some localised corrosion but with relatively low volumes \\
\hline \multirow{2}{*}{ T5 (Four isolates $+D$. desulfuricans, aerobic) } & Aerobic bacteria likely utilised oxygen and reduced general corrosion \\
\hline & SRB present, sulfate reduction suspected \\
\hline \multirow{4}{*}{ T6 (D. desulfuricans, anaerobic) } & Localised corrosion with relatively high volumes \\
\hline & Anaerobic environment reduced general corrosion \\
\hline & SRB present, sulfate reduction suspected \\
\hline & Localised corrosion with relatively high volumes \\
\hline
\end{tabular}




\section{Conclusions}

The aim of this study was to investigate laboratory tests that mimic the complex communities present in real world cases of MIC/ALWC. As part of this work, a model SRB, $D$. desulfuricans, was used throughout an 8-week corrosion study. The general corrosion rates of many of the mixed microbial test configurations were lower than that of an uninoculated control. Despite that the three mixed microbial tests (T2, T4 and T5) were nominally aerobic, it is likely the test solutions became anaerobic due to oxygen use by aerobic microbes in the milieu which may have been responsible for the reduced general/uniform corrosion. Greater localised corrosion was observed for all of the tests that included D. desulfuricans. However, the defined mixed community with $D$. desulfuricans did not lead to increased corrosion compared to tests with $D$. desulfuricans alone. The composition of the mixed microbial communities changed over the duration of the test and key differences were observed between the planktonic and biofilm communities. More laboratory-based experimental work is required to determine optimal microbial communities and test conditions for ALWC studies. Finally, the metabolomic or transcriptomic aspects relevant to the microbe/corrosion processes should be considered for a further study. It is likely that such studies would give further useful insights into MIC and ALWC.

Supplementary Materials: The following are available online at https:/ / www.mdpi.com/2624-5 $558 / 2 / 2 / 8 /$ s1, Table S1: Summary of example MIC studies using defined multispecies microbial consortia (WL-weight loss test method, $\mathrm{CR}$ - corrosion rate), Table S2: Putative metabolic activities of microbes present in metabarcoding profiles identified using METAGENassist, Figure S1: XRD scans of products formed on DH36 coupons in six treatments at 8 weeks. The three highest peaks observed match to the Fe component of the carbon steel coupons used.

Author Contributions: Conceptualisation, all authors; methodology, all authors; validation, all authors; formal analysis, H.C.P.; investigation, H.C.P.; writing—original draft preparation, H.C.P.; writing-review and editing, all authors; visualization, H.C.P.; supervision, S.A.W. and L.L.B. All authors have read and agreed to the published version of the manuscript.

Funding: This research received no external funding.

Data Availability Statement: The data presented in this study are available on request from the corresponding author. The microbial sequencing data is planned to be deposited in the NCBI database.

Acknowledgments: We would like to thank Melanie Thomson (previously of Deakin University) for providing the $D$. desulfuricans used in this study.

Conflicts of Interest: The authors declare no conflict of interest.

\section{References}

1. Ijsseling, F. General guidelines for corrosion testing of materials for marine applications: Literature review on sea water as test environment. Br. Corros. J. 1989, 24, 53-78. [CrossRef]

2. Little, B.J.; Lee, J.S. Microbiologically influenced corrosion. In Kirk-Othmer Encyclopedia of Chemical Technology; Wiley-Interscience: Hoboken, NJ, USA, 2009; pp. 1-38.

3. Christie, J. The effect of MIC and other corrosion mechanisms on the global ports infrastructure. In Proceedings of the MIC-An International Perspective, Perth, Australia, 14-16 February 2007.

4. Jeffrey, R.J.; Melchers, R.E. Effect of vertical length on corrosion of steel in the tidal zone. Corrosion 2009, 65, 695-702. [CrossRef]

5. Beech, I.B.; Campbell, S.A. Accelerated low water corrosion of carbon steel in the presence of a biofilm harbouring sulphatereducing and sulphur-oxidising bacteria recovered from a marine sediment. Electrochim. Acta 2008, 54, 14-21. [CrossRef]

6. Dang, H.; Lovell, C.R. Microbial surface colonization and biofilm development in marine environments. Microbiol. Mol. Biol. Rev. 2016, 80, 91-138. [CrossRef] [PubMed]

7. Flemming, H.-C.; Wuertz, S. Bacteria and archaea on Earth and their abundance in biofilms. Nat. Rev. Microbiol. 2019, 17, 247-260. [CrossRef] [PubMed]

8. Little, B.; Ray, R.; Pope, R. Relationship between corrosion and the biological sulfur cycle: A review. Corrosion 2000, 56, 433-443. [CrossRef]

9. Malard, E.; Gueuné, H.; Fagot, A.; Lemière, A.; Sjogren, L.; Tidblad, J.; Sanchez-Amaya, J.M.; Muijzer, G.; Marty, F.; Quillet, L.; et al. Microbiologically Induced Corrosion of Steel Structures in Port Environment: Improving Prediction and Diagnosis of ALWC (MICSIPE); RFCS Publications: Luxembourg, 2013. 
10. Païssé, S.; Ghiglione, J.F.; Marty, F.; Abbas, B.; Gueuné, H.; Amaya, J.M.S.; Muyzer, G.; Quillet, L. Sulfate-reducing bacteria inhabiting natural corrosion deposits from marine steel structures. Appl. Microbiol. Biotechnol. 2013, 97, 7493-7504. [CrossRef]

11. Videla, H.A.; Herrera, L.K.; Edyvean, G. An updated overview of SRB induced corrosion and protection of carbon steel. In Proceedings of the NACE Corrosion, Houston, TX, USA, 3-7 April 2005; NACE International: Houston, TX, USA, 2005; p. 05488.

12. Enning, D.; Venzlaff, H.; Garrelfs, J.; Dinh, H.T.; Meyer, V.; Mayrhofer, K.; Hassel, A.W.; Stratmann, M.; Widdel, F. Marine sulfate-reducing bacteria cause serious corrosion of iron under electroconductive biogenic mineral crust. Environ. Microbiol. 2012, 14, 1772-1787. [CrossRef]

13. Gehrke, T.; Sand, W. Interactions between microorganisms and physiochemical factors cause MIC of steel pilings in harbors (ALWC). In Proceedings of the NACE Corrosion, San Diego, CA, USA, 16-20 March 2003; NACE International: Houston, TX, USA, 2003; p. 03557.

14. Sand, W.; Gehrke, T. Microbially influenced corrosion of steel in aqueous environments. Rev. Environ. Sci. Biotechnol. 2003, 2, 169-176. [CrossRef]

15. Gubner, R.; Beech, I. Statistical assessment of the risk of the accelerated low-water corrosion in the marine environment. In Proceedings of the NACE Corrosion, San Antonio, TX, USA, 25-30 April 1999; NACE International: Houston, TX, USA, 1999 ; p. 318.

16. Javadhastri, R. Microbiologically Influenced Corrosion-An Engineering Insight; Springer: London, UK, 2008 ; pp. 125-139.

17. Smith, M.; Bardiau, M.; Brennan, R.; Burgess, H.; Caplin, J.; Ray, S.; Urios, T. Accelerated low water corrosion: The microbial sulfur cycle in microcosm. NPJ Mater. Degrad. 2019, 3, 37. [CrossRef]

18. Barco, R.A.; Hoffman, C.L.; Ramírez, G.A.; Toner, B.M.; Edwards, K.J.; Sylvan, J.B. In-situ incubation of iron-sulfur mineral reveals a diverse chemolithoautotrophic community and a new biogeochemical role for Thiomicrospira. Environ. Microbiol. 2017, 19, 1322-1337. [CrossRef]

19. Celikkol-Aydin, S.; Gaylarde, C.C.; Lee, T.; Melchers, R.E.; Witt, D.L.; Beech, I.B. 16S rRNA gene profiling of planktonic and biofilm microbial populations in the Gulf of Guinea using Illumina NGS. Mar. Environ. Res. 2016, 122, 105-112. [CrossRef] [PubMed]

20. Dang, H.; Chen, R.; Wang, L.; Shao, S.; Dai, L.; Ye, Y.; Guo, L.; Huang, G.; Klotz, M.G. Molecular characterization of putative biocorroding microbiota with a novel niche detection of Epsilon and Zetaproteobacteria in Pacific Ocean coastal seawaters. Environ. Microbiol. 2011, 13, 3059-3074. [CrossRef] [PubMed]

21. Phan, H.C.; Wade, S.A.; Blackall, L.L. Is marine sediment the source of microbes associated with accelerated low water corrosion? Appl. Microbiol. Biotechnol. 2019, 103, 449-459. [CrossRef] [PubMed]

22. Lee, J.; Ray, R.; Lemieux, E.; Falster, A.; Little, B. An evaluation of carbon steel corrosion under stagnant seawater conditions. Biofouling 2004, 20, 237-247. [CrossRef] [PubMed]

23. Marty, F.; Gueune, H.; Malard, E.; Sánchez-Amaya, J.M.; Sjögren, L.; Abbas, B.; Quillet, L.; van Loosdrecht, M.C.M.; Muyzer, G. Identification of key factors in accelerated low water corrosion through experimental simulation of tidal conditions: Influence of stimulated indigenous microbiota. Biofouling 2014, 30, 281-297. [CrossRef]

24. Pillay, C.; Lin, J. Metal corrosion by aerobic bacteria isolated from stimulated corrosion systems: Effects of additional nitrate sources. Int. Biodeter. Biodegrad. 2013, 83, 158-165. [CrossRef]

25. Wade, S.; Blackall, L. Development of a laboratory test for microbial involvement in accelerated low water corrosion. Microbiol. Aust. 2018, 39, 170-172. [CrossRef]

26. Enning, D.; Garrelfs, J. Corrosion of iron by sulfate-reducing bacteria: New views of an old problem. Appl. Environ. Microbiol. 2014, 80, 1226-1236. [CrossRef]

27. Li, Y.; Xu, D.; Chen, C.; Li, X.; Jia, R.; Zhang, D.; Sand, W.; Wang, F.; Gu, T. Anaerobic microbiologically influenced corrosion mechanisms interpreted using bioenergetics and bioelectrochemistry: A review. J. Mater. Sci Technol. 2018, 34, 1713-1718. [CrossRef]

28. Martin, A.; Auger, E.A.; Blum, P.H.; Schultz, J.E. Genetic basis of starvation survival in nondifferentiating bacteria. Annu. Rev. Microbiol. 1989, 43, 293-316. [CrossRef]

29. Xu, D.; Gu, T. Carbon source starvation triggered more aggressive corrosion against carbon steel by the Desulfovibrio vulgaris biofilm. Int. Biodeter. Biodegrad. 2014, 91, 74-81. [CrossRef]

30. Salgar-Chaparro, S.J.; Lepkova, K.; Pojtanabuntoeng, T.; Darwin, A.; Machuca, L.L. Nutrient level determines biofilm characteristics and subsequent impact on microbial corrosion and biocide effectiveness. Appl. Environ. Microbiol. 2020, 86, e02885-e02919. [CrossRef] [PubMed]

31. Wade, S.A.; Javed, M.A.; Palombo, E.A.; McArthur, S.L.; Stoddart, P.R. On the need for more realistic experimental conditions in laboratory-based microbiologically influenced corrosion testing. Int. Biodeter. Biodegrad. 2017, 121, 97-106. [CrossRef]

32. Javed, M.; Neil, W.; McAdam, G.; Wade, S. Effect of sulphate-reducing bacteria on the microbiologically influenced corrosion of ten different metals using constant test conditions. Int. Biodeter. Biodegrad. 2017, 125, 73-85. [CrossRef]

33. Li, H.-B.; Zhang, L.-P.; Chen, S.-F. Halomonas korlensis sp. nov., a moderately halophilic, denitrifying bacterium isolated from saline and alkaline soil. Int. J. Syst. Evol. Microbiol. 2008, 58, 2582-2588. [CrossRef] [PubMed]

34. Mahendran, S.; Sankaralingam, S.; Shankar, T.; Vijayabaskar, P. Alkalophilic protease enzyme production from estuarine Bacillus aquimaris. World J. Fish Mar. Sci. 2010, 2, 436-443.

35. Marques, J.M.; de Almeida, F.P.; Lins, U.; Seldin, L.; Korenblum, E. Nitrate treatment effects on bacterial community biofilm formed on carbon steel in produced water stirred tank bioreactor. World J. Microbiol. Biotechnol. 2012, 28, 2355-2363. [CrossRef] [PubMed] 
36. Phan, H.C.; Wade, S.A.; Blackall, L.L. Microbial communities of orange tubercles in accelerated low water corrosion. Appl. Environ. Microbiol. 2020, 86, e00610-e00620. [CrossRef]

37. Cavaleiro, A.J.; Abreu, A.A.; Sousa, D.Z.; Pereira, M.A.; Alves, M.M. The role of marine anaerobic bacteria and archaea in bioenergy production. In Management of Microbial Resources in the Environment; Malik, A., Grohmann, E., Alves, M., Eds.; Springer: Dordrecht, The Netherlands, 2013; pp. 445-469.

38. Makita, H. Iron-oxidizing bacteria in marine environments: Recent progresses and future directions. World J. Microbiol. Biotechnol. 2018, 34, 110. [CrossRef]

39. Garrity, G.M.; Bell, J.A.; Lilburn, T. Rhodobacteraceae. In Bergey's Manual of Systematic Bacteriology: The Proteobacteria: Part C: The Alpha-, Beta-, Delta-, and Epsilonproteobacteria; Brenner, D.J., Krieg, N.R., Staley, J.T., Eds.; Springer Science \& Business Media: New York, NY, USA, 2006; Volume 2, pp. 161-229.

40. Javed, M.A.; Stoddart, P.R.; Wade, S.A. Corrosion of carbon steel by sulphate reducing bacteria: Initial attachment and the role of ferrous ions. Corros. Sci. 2015, 93, 48-57. [CrossRef]

41. ASTM G1 Standard Practice for Preparing, Cleaning, and Evaluating Corrosion Test Specimens; ASTM International: West Conshohocken, PA, USA, 2017.

42. Cypionka, H. Oxygen respiration by Desulfovibrio species. Ann. Rev. Microbiol. 2000, 54, 827-848. [CrossRef]

43. Lobo, S.A.; Melo, A.M.; Carita, J.N.; Teixeira, M.; Saraiva, L.M. The anaerobe Desulfovibrio desulfuricans ATCC 27774 grows at nearly atmospheric oxygen levels. FEBS Lett. 2007, 581, 433-436. [CrossRef]

44. Kwon, M.J.; O’Loughlin, E.J.; Boyanov, M.I.; Brulc, J.M.; Johnston, E.R.; Kemner, K.M.; Dionysios, A.; Antonopoulo, D.A. Impact of organic carbon electron donors on microbial community development under iron- and sulfate-reducing conditions. PLoS ONE 2016, 11, e0146689. [CrossRef]

45. Zhan, M.; Liu, X.; Li, Y.; Wang, G.; Wang, Z.; Wen, J. Microbial community and metabolic pathway succession driven by changed nutrient inputs in tailings: Effects of different nutrients on tailing remediation. Sci. Rep. 2017, 7, 474. [CrossRef]

46. Parthipan, P.; Elumalai, P.; Ting, Y.P.; Rahman, P.K.; Rajasekar, A. Characterization of hydrocarbon degrading bacteria isolated from Indian crude oil reservoir and their influence on biocorrosion of carbon steel API 5LX. Int. Biodeter. Biodegrad. 2018, 129, 67-80. [CrossRef]

47. Rajasekar, A.; Babu, G.T.; Pandian, K.S.; Maruthamuthu, S.; Palaniswamy, N.; Rajendran, A. Biodegradation and corrosion behavior of manganese oxidizer Bacillus cereus ACE4 in diesel transporting pipeline. Corros. Sci. 2007, 49, 2694-2710. [CrossRef]

48. Xu, D.; Li, Y.; Song, F.; Gu, T. Laboratory investigation of microbiologically influenced corrosion of C1018 carbon steel by nitrate reducing bacterium Bacillus licheniformis. Corros. Sci. 2013, 77, 385-390. [CrossRef]

49. Guo, Z.; Liu, T.; Cheng, Y.F.; Guo, N.; Yin, Y. Adhesion of Bacillus subtilis and Pseudoalteromonas lipolytica to steel in a seawater environment and their effects on corrosion. Colloids Surf. B 2017, 157, 157-165. [CrossRef]

50. Jayaraman, A.; Cheng, E.T.; Earthman, J.C.; Wood, T.K. Axenic aerobic biofilms inhibit corrosion of SAE 1018 steel through oxygen depletion. Appl. Microbiol. Biotechnol. 1997, 48, 11-17. [CrossRef] [PubMed]

51. Jayaraman, A.; Hallock, P.; Carson, R.; Lee, C.-C.; Mansfeld, F.; Wood, T. Inhibiting sulfate-reducing bacteria in biofilms on steel with antimicrobial peptides generated in situ. Appl. Microbiol. Biotechnol. 1999, 52, 267-275. [CrossRef] [PubMed]

52. Karn, S.K.; Guan, F.; Duan, J. Bacillus sp. acting as dual role for corrosion induction and corrosion inhibition with carbon steel. Front. Microbiol. 2017, 8, 2038. [CrossRef]

53. Zuo, R.; Wood, T.K. Inhibiting mild steel corrosion from sulfate-reducing and iron-oxidizing bacteria using gramicidin-Sproducing biofilms. Appl. Microbiol. Biotechnol. 2004, 65, 747-753. [CrossRef] [PubMed]

54. Beech, I.B.; Sunner, J. Sulphate-reducing bacteria and their role in corrosion of ferrous materials. In Sulphate-Reducing Bacteria: Environmental and Engineered Systems; Barton, L.L., Hamilton, W.A., Eds.; Cambridge University Press: Cambridge, UK, 2007; pp. $459-482$.

55. Hamilton, W. Microbially influenced corrosion as a model system for the study of metal microbe interactions: A unifying electron transfer hypothesis. Biofouling 2003, 19, 65-76. [CrossRef]

56. Hardy, J.; Bown, J. The corrosion of mild steel by biogenic sulfide films exposed to air. Corrosion 1984, 40, 650-654. [CrossRef]

57. Lee, W.; Lewandowski, Z.; Morrison, M.; Characklis, W.G.; Avci, R.; Nielsen, P.H. Corrosion of mild steel underneath aerobic biofilms containing sulfate-reducing bacteria part II: At high dissolved oxygen concentration. Biofouling 1993, 7, 217-239. [CrossRef]

58. Li, X.; Xiao, H.; Zhang, W.; Li, Y.; Tang, X.; Duan, J.; Yang, Z.; Wang, J.; Guan, F.; Ding, G. Analysis of cultivable aerobic bacterial community composition and screening for facultative sulfate-reducing bacteria in marine corrosive steel. J. Oceanol. Limnol. 2019, 37, 600-614. [CrossRef]

59. Qian, H.; Ju, P.; Zhang, D.; Ma, L.; Hu, Y.; Li, Z.; Huang, L.; Lou, Y.; Du, C. Effect of dissolved oxygen concentration on the microbiologically influenced corrosion of Q235 carbon steel by halophilic archaea Natronorubrum tibetense. Front. Microbiol. 2019, 10, 844. [CrossRef]

60. McBeth, J.M.; Emerson, D. In situ microbial community succession on mild steel in estuarine and marine environments: Exploring the role of iron-oxidizing bacteria. Front. Microbiol. 2016, 7, 1-14. [CrossRef] [PubMed]

61. Tan, C.H.; Lee, K.W.K.; Burmølle, M.; Kjelleberg, S.; Rice, S.A. All together now: Experimental multispecies biofilm model systems. Environ. Microbiol. 2017, 19, 42-53. [CrossRef] 